\title{
Gordona hydrophobica sp. nov., Isolated from Biofilters for Waste Gas Treatment
}

\author{
BERND BENDINGER, ${ }^{1 *}$ FREDERICK A. RAINEY ${ }^{2}$ REINER M. KROPPENSTEDT, ${ }^{2}$ \\ MICHAEL MOORMANN, ${ }^{3}$ AND STEFAN KLATTE ${ }^{2}$ \\ EWE Aktiengesellschaft, Abteilung Abfallwirtschaft, Labor für Umweltanalytik, D-49661 Cloppenburg, ${ }^{1}$ \\ DSM-Deutsche Sammlung von Mikroorganismen und Zellkulturen GmbH, D-38124 Braunschweig, ${ }^{2}$ \\ and Abteilung Mikrobiologie, Universität Osnabrück, D-49069 Osnabrück, ${ }^{3}$ Germany
}

\begin{abstract}
The taxonomic position of Gordona sp. strain DSM $44015^{\mathrm{T}}$, isolated from the packing material of a biofilter used for biological odor abatement of animal rendering emissions, has been clarified by a polyphasic study comprising chemotaxonomic, sequencing, and phenotypic results. The strain possesses a wall chemotype IV, MK-9 $\left(\mathrm{H}_{2}\right)$, as the predominant menaquinone; relatively long-chain mycolic acids (54 to 62 carbon atoms); and straight-chain, saturated, and monounsaturated fatty acids with considerable amounts of tuberculostearic acid. The polar lipids include phosphatidylethanolamine, and the G+C content of the DNA is 69 mol\%. Similarity values for genes encoding $16 S$ rRNA indicate that Gordona sp. strain DSM $44015^{\mathrm{T}}$ represents a new species within the genus Gordona for which the name Gordona hydrophobica is proposed.
\end{abstract}

Actinomycetes containing mycolic acids have many common cell wall characteristics and form a suprageneric group (24, 32-34) comprising the genera Conynebacterium, Rhodococcus, Gordona, Nocardia, Mycobacterium, Tsukamurella, and Dietzia (28). Numerical taxonomic, chemical, and molecular systematic methods $(8,9)$ have been used to differentiate among the taxa.

Up to date, six species of the genus Gordona $(33,35)$ are known: Gordona bronchialis, Gordona rubropertincta, Gordona terrae (35), Gordona sputi $(36,38)$, Gordona aichiensis $(18,37)$, and Gordona amarae $(18,21)$. The taxonomic history of the genus Gordona is confusing because of renamings of original isolates (36) and recent transfers of strains from the genus Rhodococcus or Nocardia to the genus Gordona (18). Polyphasic taxonomic studies, including chemotaxonomic, phylogenetic, and phenotypic properties, clearly separated the species of the genus Gordona from those of other actinomycete genera (18).

Until now, Gordona species have been regarded primarily as opportunistic pathogens isolated from sputum of humans $(G$. bronchialis, $G$. aichiensis, and $G$. sputi) suffering from pulmonary lesions (35-37). Compared with the number of isolates from sputum, few Gordona strains have been isolated from terrestrial or aquatic habitats where mycolic acid-containing actinomycetes are generally known to be widely distributed (9). Only two Gordona species, $G$. terrae and $G$. rubropertincta, derive from soil $(35,36)$. Another strain that has recently been affiliated with the taxon Gordona, $G$. amarae (18), had been isolated from foam formed on the surface of aeration tanks in activated sludge-sewage-treatment plants (21). Gordona strains have also been isolated from the packing material (tree bark compost) of biofilters used for the treatment of malodorous animal rendering emissions $(1,2)$. These strains were able to use readily volatile, poorly water-soluble carbonyl compounds such as aldehydes and ketones contained in the waste gases, thus suggesting a contribution of these bacteria to the deodorization of the off-gases (1). Furthermore, these strains were found to possess extremely hydrophobic cell surfaces,

* Corresponding author. Mailing address: EWE Aktiengesellschaft, Labor für Umweltanalytik, Bürgerparkstraße, D-49661 Cloppenburg, Germany. Phone: 49-4471-13381. Fax: 49-4471-13389. which has been related to the presence of unshielded longchain mycolic acids (3). The aim of this study was to clarify the taxonomic position of one of these strains, Gordona sp. strain DSM $44015^{\mathbf{T}}$, on the basis of further chemotaxonomic, physiological, and genetic characteristics.

\section{MATERIALS AND METHODS}

Bacterial strains and cultivation. Gordona hydrophobica (DSM $44015^{\mathrm{T}}$ ) was deposited at the DSM-Deutsche Sammlung von Mikroorganismen und Zellkulturen. For analysis of cellular fatty acid composition, $G$. hydrophobica was grown on TSB agar (3\% [wt/vol] Trypticase soy broth [BBL], 1.5\% [wt/vol] Bacto Agar [Difco]) for 4 days at $28^{\circ} \mathrm{C}$. For biochemical examination, G. hydrophobica was harvested from GYM agar $(0.4 \%$ [wt/vol] D-glucose, $0.4 \%$ [wt/vol] yeast extract, $1 \%$ [wt/vol] malt extract, $1.2 \%$ [wt/vol] agar no. 1 [OXOID]) after 3 days at $28^{\circ} \mathrm{C}$. For determination of the $\mathrm{G}+\mathrm{C}$ content of DNA and for cell wall analysis, cell material was produced in Trypticase soy broth (BBL) for 4 days at $28^{\circ} \mathrm{C}$ on a rotary shaker, harvested by centrifugation, and washed twice with distilled water.

Cell wall chemistry. Isoprenoid quinones, polar lipids, cell wall diamino acids, and sugars were examined according to published methods (19). The acyl type of peptidoglycan was identified according to the method of Uchida and Aida (39) modified by passing the hydrolysate through an ion exchanger (Bond Elut column SCX, catalog no. 617303; Analytichem). Fatty acid methyl esters were prepared from wet cells ( 40 to $70 \mathrm{mg}$ ) as described previously (31) and identified by gas chromatography with a model 5898A Microbial Identification System (Microbial ID, Newark, Del.). Chain lengths of trimethylsilylated derivatives of mycolic acids (28) were determined by high-temperature gas chromatography on an HP 5790A gas chromatograph (Hewlett-Packard) equipped with a flame ionization detector on a 12-m HT5 column (part no. 051385; SGE, Ringwood, Victoria, Australia) with $\mathrm{H}_{2}$ as carrier gas $(30 \mathrm{ml} / \mathrm{min})$. The oven temperature was ramped from 210 to $400^{\circ} \mathrm{C}$ at $10^{\circ} \mathrm{C} / \mathrm{min}$, holding the final temperature for 7 min. Peaks of the derivatives were identified by comparing their retention times with those of standards. Pyrolysis of mycolic acid methyl esters of G. hydrophobica obtained by the method of Minnikin et al. (23) and analysis of cleavage products were performed with a model 5898A Microbial Identification System (Microbial ID) under standard conditions.

Physiological tests. Qualitative enzyme tests were performed in standard microtitration plates (F-form; Greiner, Nürtingen, Germany) according to the method of Kämpfer et al. (17). The following chromogenic substrates were added to a medium ( $\mathrm{pH} 7.2$ ) consisting of $0.05 \mathrm{M}$ Tris- $\mathrm{HCl}$ buffer, $0.05 \%$ (wt/vol) Casamino Acids (Difco), and $0.05 \%$ (wt/vol) yeast extract (Difco) at a final concentration of $2 \mathrm{mM}$ : $p$-nitrophenyl (pNP)- $\beta$-D-xyloside, pNP-phosphorylcholine, and 2-deoxythymidine- $5^{\prime}$-pNP-phosphate. The test reaction mixtures were inoculated with a standardized bacterial suspension of 0.5 to $1.0 \mathrm{McFarland}$ units in $0.9 \%$ (wt/vol) $\mathrm{NaCl}$ and incubated for $48 \mathrm{~h}$ at $28^{\circ} \mathrm{C}$. Growth on D-galactose, meso-inositol, L-rhamnose (all 1.0\% [wt/vol]), and citric acid (Na salt) $(0.1 \%$ [wt/vol]) as carbon sources was examined in yeast-nitrogen broth (Difco) (pH 7.2) at $28^{\circ} \mathrm{C}$ for 4 days. The results of the enzyme tests and carbon source utilization were evaluated visually against the results of duplicate controls.

Determination of $\mathbf{G}+\mathbf{C}$ content of DNA. The DNA was isolated by chromatography on hydroxyapatite by the procedure of Cashion et al. (5). The $G+C$ 
TABLE 1. Chemosystematic characteristics of Gordona hydrophobica and related wall chemotype IV taxa containing mycolic acids ${ }^{a}$

\begin{tabular}{|c|c|c|c|c|c|}
\hline Taxon & $\begin{array}{l}\text { Fatty acid } \\
\text { composition }^{b}\end{array}$ & $\begin{array}{l}\text { Mycolate size (no. of } \\
\text { carbon atoms) }\end{array}$ & $\begin{array}{l}\text { Presence of } \\
\text { phosphatidyl- } \\
\text { ethanolamine }^{c}\end{array}$ & Major menaquinone(s) & $\begin{array}{l}\mathrm{G}+\mathrm{C} \text { content of } \\
\text { DNA }(\mathrm{mol} \%)\end{array}$ \\
\hline Gordona hydrophobica & $\mathrm{S}, \mathrm{U}, \mathrm{T}$ & $54-62$ & + & MK-9 $\left(\mathrm{H}_{2}\right)$ & 69 \\
\hline Gordona species & $\mathrm{S}, \mathrm{U}, \mathrm{T}$ & $48-66$ & + & MK-9 $\left(\mathrm{H}_{2}\right)$ & $63-69$ \\
\hline Nocardia species & $\mathrm{S}, \mathrm{U}, \mathrm{T}$ & $44-60$ & + & MK-8 $\left(\mathrm{H}_{4}, \omega\right.$-cycl $)$ & $64-72$ \\
\hline Rhodococcus species & $\mathrm{S}, \mathrm{U}, \mathrm{T}$ & $34-52$ & + & MK-8 $\left(\mathrm{H}_{2}\right)$ & $63-73$ \\
\hline Tsukamurella species & S, U,T & $64-68$ & + & MK-9 & $67-68$ \\
\hline Mycobacterium species & $\mathrm{S}, \mathrm{U}, \mathrm{T}$ & $60-90$ & + & MK-9 $\left(\mathrm{H}_{2}\right)$ & $62-70$ \\
\hline Corynebacterium species & $\mathrm{S}, \mathrm{U}^{d}$ & $22-36$ & $v^{e}$ & MK-8 $\left(\mathrm{H}_{2}\right)$, MK-9 $\left(\mathrm{H}_{2}\right)$ & $51-67$ \\
\hline Dietzia species & $\mathbf{S}, \mathbf{U}, \mathbf{T}$ & $34-38$ & + & MK-8 $\left(\mathrm{H}_{2}\right)$ & 73 \\
\hline
\end{tabular}

${ }^{a}$ Adapted from references $8,9,18,28$, and 33 .

${ }^{b} \mathrm{~S}$, saturated; U, monounsaturated; T, tuberculostearic acid.

$c+$, present; $v$, variable.

${ }^{d}$ Tuberculostearic acid also present in Corynebacterium ammoniagenes, Corynebacterium bovis, Corynebacterium cystitidis, Corynebacterium minutissimum, Corynebacterium pilosum, Corynebacterium urealyticum, and Corynebacterium variabilis $(15,26)$.

' Phosphatidylethanolamine also present in C. ammoniagenes, C. bovis, C. cystitidis, Conynebacterium pseudodiphtheriticum, and C. urealyticum (15, 26).

content of DNA was determined by high-performance liquid chromatography (HPLC) according to the method of Mesbah et al. (22).

16S rDNA sequencing. Genomic DNA isolation and PCR-mediated amplification of the genes encoding 16S rRNA (16S rDNA) were performed as described by Rainey et al. (27). Double-stranded PCR products were sequenced with the Taq Dye-Deoxy Terminator Cycle Sequencing Kit (Applied Biosystems, Foster City, Calif.) according to the protocol of the manufacturer. Sequence reactions were electrophoresed with the Applied Biosystems 373A DNA Sequencer. The $16 \mathrm{~S}$ rDNA sequences were aligned against the sequences currently available from the public databases. Evolutionary distances were calculated according to the method of Jukes and Cantor (16). The phylogenetic dendrogram was constructed from the distance matrices by the algorithm of De Soete (6).

Nucleotide sequence accession number. The EMBL accession number for the $16 \mathrm{~S}$ rDNA sequence of $G$. hydrophobica DSM $44015^{\mathrm{T}}$ is $\mathrm{X} 87340$.

\section{RESULTS}

Cell wall analysis. The results of this study and previous chemotaxonomic analyses of $G$. hydrophobica are shown in Tables 1 and 2 along with the data for other related taxa (2). The cell wall of $G$. hydrophobica contained arabinose and ga- lactose as major cell wall sugars, meso-diaminopimelic acid as the only diamino acid (variation A1 $\gamma$ sensu Schleifer and Kandler [30]), and N-glycolated muramic acid moieties of peptidoglycan, thus possessing the characteristic wall chemotype IV sensu Lechevalier and Lechevalier (20) of genera containing mycolic acid. The polar lipids were composed of diphosphatidylglycerol, phosphatidylinositol, phosphatidylinositol mannosides, and phosphatidylethanolamine. MK-9 $\left(\mathrm{H}_{2}\right)$ was found to be the predominant menaquinone with minor amounts of MK-8 $\left(\mathrm{H}_{2}\right)$ (less than 5\%).

Cellular fatty acids. Analysis of simple fatty acids from whole cells exhibited a pattern of straight-chain, saturated, and monounsaturated fatty acids with significant amounts of tuberculostearic acid (10-methyl octadecanoic acid) (1\% 14:0, 2\% $15: 1$ cis $10,4 \% 15: 0,13 \% 16: 1$ cis $10,27 \% 16: 0,4 \% 17: 1$ cis 9 , 4\% 17:0, 2\% 10-Me-17:0, 14\% 18:1 cis 9, 1\% 18:0, 26\% 10Me-18:0). The mycolic acids of $G$. hydrophobica, as determined from trimethylsilylated derivatives by high-temperature gas

TABLE 2. Diagnostic characteristics of the Gordona species $^{a}$

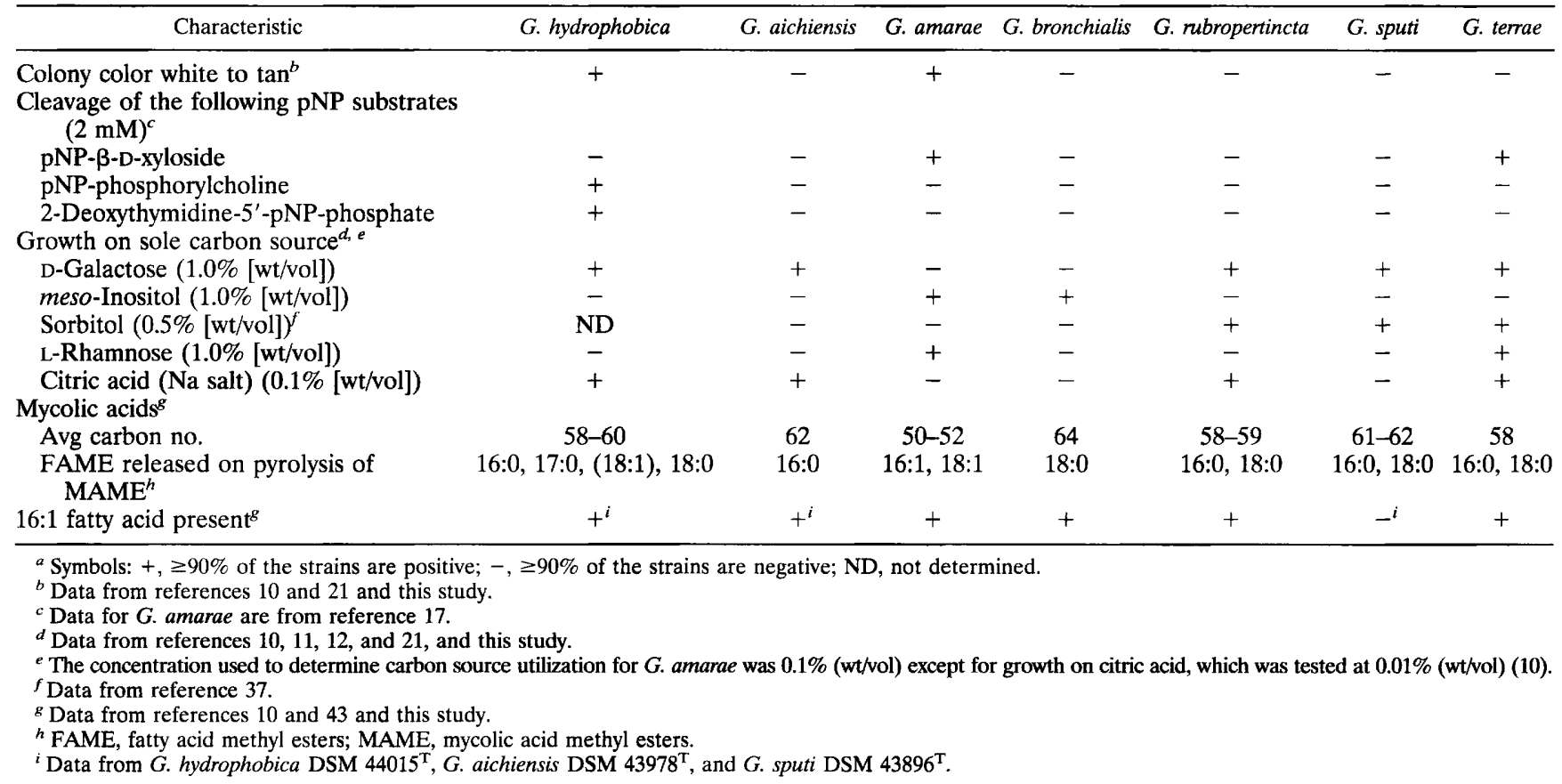




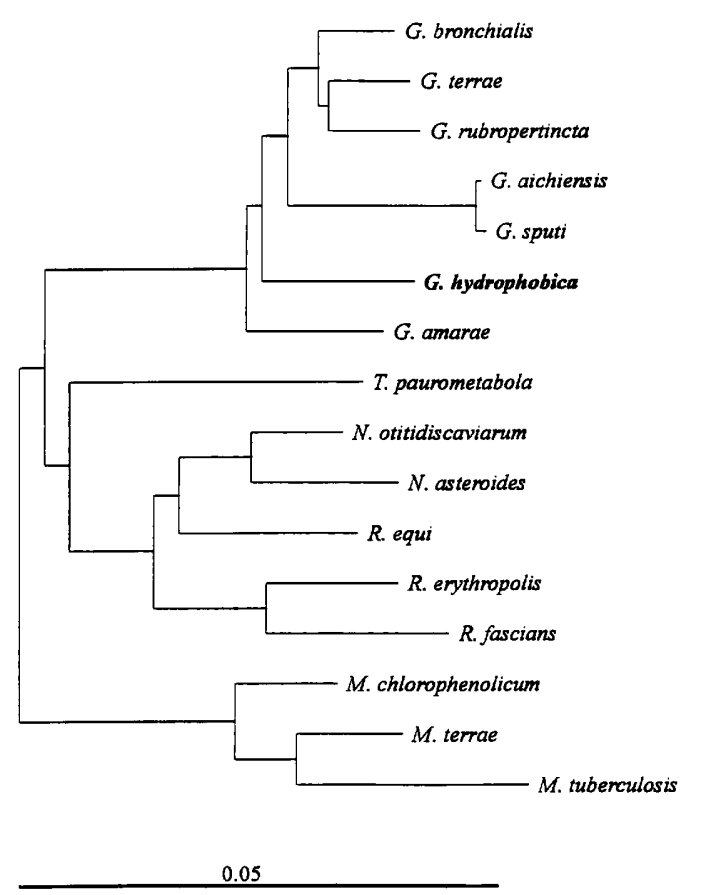

FIG. 1. Phylogenetic dendrogram indicating the relationship of G. hydrophobica to all species of the genus Gordona and related taxa. Bar $=5$ substitutions per 100 nucleotides, as determined by measuring the length of the horizontal lines connecting two species. A bootstrap analysis yielded a $100 \%$ confidence level for the position of the branch of the Gordona group.

chromatography, were similar in size as described for members of the genus Gordona $(8,43)$ (Table 2), having an overall range of 54 to 62 carbon atoms $\left(12 \% \mathrm{C}_{56}, 11 \% \mathrm{C}_{57}, 30 \% \mathrm{C}_{58}, 16 \%\right.$ $\mathrm{C}_{59}, 26 \% \mathrm{C}_{60}$, and $5 \% \mathrm{C}_{61}$ and traces of $\mathrm{C}_{54}, \mathrm{C}_{55}$, and $\mathrm{C}_{62}$ ) with a mean chain length of between 58 and 60 carbon atoms. The composition of fatty acid methyl esters released by pyrolytic cleavage of methyl mycolates was mainly 18:0 (58\%) and 16:0 $(26 \%)$, with additional amounts of 17:0 (12\%) and 18:1 cis 9 $(4 \%)$.

Physiological test. The results of physiological testing of $G$. hydrophobica are included in Table 2. G. hydrophobica could enzymatically hydrolyze the chromogenic substrates pNP- phosphorylcholine and 2-deoxythymidine-5'-pNP-phosphate, respectively, while pNP- $\beta$-D-xyloside remained uncleaved. DGalactose and citric acid (Na salt) were utilized by $G$. hydrophobica as sole carbon sources, while meso-inositol and Lrhamnose were not.

Analysis of 16S rDNA. Almost the complete $(>1,500$ nucleotides) 16S rDNA sequence was determined for $G$. hydrophobica and compared with those of reference strains of mycolic acid-containing actinomycetes. The phylogenetic dendrogram in Fig. 1 shows the relationship of $G$. hydrophobica DSM $44015^{\mathrm{T}}$ to all species of the genus Gordona and representatives of related genera for which sequence data are available. $G$. hydrophobica DSM $44015^{\mathrm{T}}$ is part of a cluster composed of all valid species composing the genus Gordona, thus being clearly separated from other mycolic acid-containing genera on the basis of $16 \mathrm{~S}$ rDNA data. Furthermore, the values for $G$. $h y$ drophobica DSM $44015^{\mathrm{T}}$ of similarity to members of the genus Gordona (Table 3) were in the range of 96.1 to $97.9 \%$ while the similarity to other genera was less than $94.1 \%$. G. hydrophobica DSM $44015^{\mathrm{T}}$ showed the highest level of similarity $(97.9 \%)$ to G. rubropertincta DSM $43197^{\mathrm{T}}$.

Determination of $\mathbf{G}+\mathbf{C}$ content of DNA. The $\mathrm{G}+\mathrm{C}$ content of DNA of $G$. hydrophobica, as determined by HPLC, was 69 $\mathrm{mol} \%$.

\section{DISCUSSION}

During the last several years, a significant number of mycolic acid-containing actinomycetes have been isolated from the environment, biotechnological plants used for soil or groundwater remediation $(4,40,41)$, and waste gas treatment plants $(7$, 25,42 ) and have been shown to degrade recalcitrant or readily volatile pollutants $(13,14,29)$. Such isolates need to be identified reliably. Chemotaxonomy is a powerful tool for differentiation among mycolic acid-containing bacteria and should be applied for their preliminary classification (2).

Strains of the genus Gordona were isolated from the packing material of biofilters used for biological odor abatement of malodorous animal rendering emissions $(1,2)$. Further taxonomic studies performed for strain DSM $44015^{\mathbf{T}}$ clarified its position within the genus Gordona. The sequence data clearly showed that $G$. hydrophobica DSM $44015^{\mathrm{T}}$ belongs to the genus Gordona and, moreover, provided evidence for the exclusion of this strain from other known species of the genus. This

TABLE 3. 16S rDNA similarity values for organisms used in this study

\begin{tabular}{|c|c|c|c|c|c|c|c|c|c|c|c|c|c|c|c|c|c|}
\hline \multirow{2}{*}{$\begin{array}{c}\text { Control } \\
\text { no. }\end{array}$} & \multirow{2}{*}{ Sp. } & \multicolumn{16}{|c|}{$\%$ 16S rDNA similarity with control no.: } \\
\hline & & 1 & 2 & 3 & 4 & 5 & 6 & 7 & 8 & 9 & 10 & 11 & 12 & 13 & 14 & 15 & 16 \\
\hline 1 & G. hydrophobica & & & & & & & & & & & & & & & & \\
\hline 2 & G. amarae & 97.4 & & & & & & & & & & & & & & & \\
\hline 3 & G. terrae & 97.4 & 97.2 & & & & & & & & & & & & & & \\
\hline 4 & G. rubropertincta & 97.9 & 97.0 & 98.4 & & & & & & & & & & & & & \\
\hline 5 & G. bronchialis & 97.1 & 97.1 & 98.3 & 98.5 & & & & & & & & & & & & \\
\hline 6 & G. aichiensis & 96.2 & 96.6 & 96.8 & 97.0 & 97.4 & & & & & & & & & & & \\
\hline 7 & G. sputi & 96.1 & 96.4 & 96.7 & 96.7 & 97.3 & 99.7 & & & & & & & & & & \\
\hline 8 & Rhodococcus equi & 93.9 & 94.0 & 94.5 & 94.2 & 94.2 & 93.1 & 93.0 & & & & & & & & & \\
\hline 9 & Rhodococcus fascians & 93.0 & 93.0 & 93.3 & 93.0 & 93.0 & 92.1 & 92.0 & 95.7 & & & & & & & & \\
\hline 10 & Rhodococcus erythropolis & 93.4 & 93.7 & 93.3 & 93.0 & 93.3 & 92.9 & 92.9 & 96.1 & 97.1 & & & & & & & \\
\hline 11 & Nocardia asteroides & 93.2 & 93.8 & 93.0 & 93.1 & 93.3 & 92.6 & 92.6 & 95.9 & 95.0 & 95.7 & & & & & & \\
\hline 12 & Nocardia otitidiscaviarum & 94.1 & 94.3 & 94.1 & 94.6 & 94.7 & 93.3 & 93.3 & 97.2 & 95.0 & 96.0 & 97.8 & & & & & \\
\hline 13 & Tsukamurella paurometabola & 93.4 & 94.5 & 93.3 & 93.2 & 93.3 & 93.4 & 93.4 & 94.7 & 94.0 & 94.6 & 94.3 & 94.4 & & & & \\
\hline 14 & Mycobacterium chlorophenolicum & 93.7 & 94.0 & 93.4 & 93.1 & 93.7 & 92.8 & 92.8 & 93.5 & 93.4 & 94.0 & 94.2 & 93.9 & 94.5 & & & \\
\hline 15 & Mycobacterium terrae & 92.8 & 93.2 & 93.0 & 92.6 & 93.0 & 92.8 & 92.5 & 92.9 & 93.0 & 93.2 & 93.3 & 93.0 & 94.0 & 97.4 & & \\
\hline 16 & Mycobacterium tuberculosis & 91.8 & 91.8 & 92.3 & 91.6 & 92.4 & 91.2 & 91.0 & 92.0 & 92.0 & 92.0 & 92.5 & 91.7 & 92.1 & 96.4 & 96.7 & \\
\hline
\end{tabular}


assignment was supported by the chemotaxonomic data obtained for the strain. Among the Gordona species, only $G$. hydrophobica DSM $44015^{\mathrm{T}}$ released the $17: 0$ fatty acid by pyrolytic cleavage of mycolic acids. In addition, phenotypic properties differentiated $G$. hydrophobica DSM $44015^{\mathrm{T}}$ from the other described Gordona species. The new strain was the only one that hydrolyzed the chromogenic substrates pNP-phosphorylcholine and 2-deoxythymidine-5' -pNP-phosphate. On the basis of the data presented here, it is proposed that $G$. hydrophobica DSM $44015^{\mathrm{T}}$ be assigned as the type strain of a new Gordona species, $G$. hydrophobica.

Description of Gordona hydrophobica sp. nov. Gordona hydrophobica (hy.dro.pho'bi.ca. Gr. n. hydro, water; Gr. adj. phobos, fear, dread; M.L. adj. hydrophobica, water avoiding, water repellent, related to hydrophobic). The species description below is based on our own data and additional information obtained from references 1,2 , and 3 .

Gram-positive, non-acid-fast, regular, long rods (2 to $3 \mu \mathrm{m}$ ) that are nonmotile, grow amycelially, and undergo a rod-coccus cycle. Light microscopy of colony or liquid culture growth shows cells mostly in aggregates. Growth in liquid culture is clear with a pellicle on the surface that rises up at the glass wall of a culture tube.

Tannish to white colonies are formed on various media. The colony morphology of the type strain is rough and flat with irregular margins. Upon primary isolation, colonies may also be convex with entire or undulate margins and a smooth surface. Subcultivation of a smooth colony on complex medium agar plates yields smooth as well as rough colonies, whereas a rough variant yields only rough colonies. Rough variants of $G$. hydrophobica have an extremely high cell surface hydrophobicity which is reduced significantly in variants forming smooth colonies.

Cleaves the pNP substrates pNP-phosphorylcholine and 2-deoxythymidine-5'-pNP-phosphate but not pNP- $\beta$-D-xyloside. Uses D-galactose, citric acid ( $\mathrm{Na}$ salt), succinic acid ( $\mathrm{Na}$ salt), propionic acid, and leucine as sole carbon source but does not use meso-inositol, L-rhamnose, gluconic acid, adipic acid, 5-aminovaleric acid, aspartic acid, asparagine, ribose, and arabinose. Does not decompose tyrosine, adenine, and xanthine and does not produce acid from sucrose aerobically or anaerobically.

Growth occurs on the readily volatile carbonyl compounds methylpropanal, 3-methylbutanal, 2-methylbutanal, butanone, 2-pentanone, and 4-methyl-2-pentanone when added as sole carbon sources into sealed agar slope cultures.

The cell wall contains meso-diaminopimelic acid as the only diamino acid, arabinose and galactose as major cell wall sugars, and $N$-glycolyl muramic acid moieties. The predominant isoprenolog is MK-9 $\left(\mathrm{H}_{2}\right)$; minor amounts of MK-8 $\left(\mathrm{H}_{2}\right)$ are also present. The polar lipids include diphosphatidylglycerol, phosphatidylethanolamine, phosphatidylinositol, and phosphatidylinositol mannosides. Contains major amounts of straight-chain, saturated, and monounsaturated fatty acids and tuberculostearic acid. Mycolic acids with 54 to 62 carbon atoms are present. Upon pyrolysis gas chromatography of mycolates, the fatty acids 16:0, 17:0, 18:0, and 18:1 are released.

The $\mathrm{G}+\mathrm{C}$ content of the DNA is $69 \mathrm{~mol} \%$.

Isolated from packing material (tree bark compost) of biofilters for deodorization of animal rendering emissions.

The type strain is $1610 / 1 \mathrm{~b}$ (=DSM $44015^{\mathrm{T}}$ ).

\section{REFERENCES}

1. Bendinger, B. 1992. Ph.D. thesis. Universität Osnabrück, Osnabrück, Germany.

2. Bendinger, B., R. M. Kroppenstedt, S. Klatte, and K. Altendorf. 1992. Che- motaxonomic differentiation of coryneform bacteria isolated from biofilters. Int. J. Syst. Bacteriol. 42:474-486.

3. Bendinger, B. H. H. M. Rijnaarts, K. Altendorf, and A. J. B. Zehnder. 1993. Physicochemical cell surface and adhesive properties of coryneform bacteria related to the presence and chain length of mycolic acids. Appl. Environ. Microbiol. 59:3973-3977.

4. Briglia, M., P. J. M. Middeldorp, and M. S. Salkinoja-Salonen. 1994. Mineralization performance of Rhodococcus chlorophenolicus strain PCP-1 in contaminated soil simulating on-site conditions. Soil Biol. Biochem. 26:377385 .

5. Cashion, P., M. A. Holder-Franklin, J. McCully, and M. Franklin. 1977. A rapid method for the base ratio determination of bacterial DNA. Anal. Biochem. 81:461-466.

6. De Soete, G. 1983. A least squares algorithm for fitting additive trees to proximity data. Psychometrika 48:621-626.

7. Ewers, J., W. Clemens, and H. J. Knackmuss. 1991. Biodegradation of chloroethenes using isopropene as a co-substrate, p. 77-83. In H. Verachtert and W. Verstraete (ed.), International Symposium on Environmental Biotechnology. Royal Flemish Society of Engineers, Antwerp, Belgium.

8. Goodfellow, M. 1989. Genus Rhodococcus Zopf 1891, p. 2362-2371. In S. T. Williams, M. E. Sharpe, and J. G. Holt (ed.), Bergey's manual of systematic bacteriology, vol. 4. Williams and Wilkins, Baltimore.

9. Goodfellow, M. 1992. The family Nocardiaceae, p. 1188-1213. In A. Balows, H. G. Trüper, M. Dworkin, W. Harder, and K. H. Schleifer (ed.), The prokaryotes, 2nd ed. Springer-Verlag, New York.

10. Goodfellow, M., D. E. Minnikin, C. Todd, G. Alderson, S. M. Minnikin, and M. D. Collins. 1982. Numerical and chemical classification of Nocardia amarae. J. Gen. Microbiol. 128:1283-1297.

11. Goodfellow, M., E. G. Thomas, A. C. Ward, and A. L. James. 1990. Classification and identification of rhodococci. Zentralbl. Bakteriol. 274:299-315.

12. Goodfellow, M., J. Zakrzewska-Czerwinska, E. G. Thomas, M. Mordarski, A. C. Ward, and A. L. James. 1991. Polyphasic taxonomic study of the genera Gordona and Tsukamurella including the description of Tsukamurella wratislaviensis sp. nov. Zentralbl. Bakteriol. 275:162-178.

13. Häggblom, M. M., D. Janke, and M. S. Salkinoja-Salonen. 1989. Transformation of chlorinated phenolic compounds in the genus Rhodococcus. Microb. Ecol. 18:147-159.

14. Heitkamp, M. A., and C. E. Cerniglia. 1989. Polycyclic aromatic hydrocarbon degradation by a Mycobacterium sp. in microcosms containing sediment and water from a pristine ecosystem. Appl. Environ. Microbiol. 55:1968-1973.

15. Herrera-Alcaraz, E. A., P. L. Valero-Guillén, F. Martin-Luengo, and F. Soriano. 1990. Taxonomic implications of the chemical analysis of the D2 group of corynebacteria. FEMS Microbiol. Lett. 72:341-344.

16. Jukes, T. H., and C. R. Cantor. 1969. Evolution of protein molecules, p. 21-132. In H. N. Munro (ed.), Mammalian protein metabolism. Academic Press, New York.

17. Kämpfer, P., W. Dott, and R. M. Kroppenstedt. 1990. Numerical classification and identification of some nocardioform bacteria. J. Gen. Appl. Microbiol. 36:309-391.

18. Klatte, S., F. A. Rainey, and R. M. Kroppenstedt. 1994. Transfer of Rhodococcus aichiensis Tsukamura 1982 and Nocardia amarae Lechevalier and Lechevalier 1974 to the genus Gordona as Gordona aichiensis comb. nov. and Gordona amarae comb. nov. Int. J. Syst. Bacteriol. 44:769-773.

19. Kothe, H. W., G. Vobis, R. M. Kroppenstedt, and A. Henssen. 1989. A taxonomic study of mycolateless, wall chemotype IV actinomycetes. Syst. Appl. Microbiol. 12:61-69.

20. Lechevalier, H. A., and M. P. Lechevalier. 1970. Chemical composition as a criterion in the classification of aerobic actinomycetes. Int. J. Syst. Bacteriol. 20:435-444.

21. Lechevalier, M. P., and H. A. Lechevalier. 1974. Nocardia amarae sp. nov., an actinomycete common in foaming activated sludge. Int. J. Syst. Bacteriol. 24:278-288.

22. Mesbah, M., U. Premachandran, and W. B. Whitman. 1989. Precise measurement of the $\mathrm{G}+\mathrm{C}$ content of deoxyribonucleic acid by high-performance liquid chromatography. Int. J. Syst. Bacteriol. 39:159-167.

23. Minnikin, D. E., I. G. Hutchinson, A. B. Caldicott, and M. Goodfellow. 1980. Thin-layer chromatography of methanolysates of mycolic acid-containing bacteria. J. Chromatogr. 188:221-233.

24. Mordarski, M., M. Goodfellow, A. Tkacz, G. Pulverer, and K. P. Schaal 1980. Ribosomal ribonucleic acid similarities in the classification of Rhodococcus and related taxa. J. Gen. Microbiol. 118:313-319.

25. Ottengraf, S. P. P. J. J. P. Meesters, A. H. C. Van den Oever, and H. R Rozema. 1986. Biological elimination of volatile xenobiotic compounds in biofilters. Bioprocess Eng. 1:61-69.

26. Pitcher, D., A. Soto, F. Soriano, and P. Valero-Guillén. 1992. Classification of coryneform bacteria associated with human urinary tract infection (group D2) as Corynebacterium urealyticum sp. nov. Int. J. Syst. Bacteriol. 42:178181

27. Rainey, F. A., M. Dorsch, H. W. Morgan, and E. Stackebrandt. 1992. 16S rDNA analysis of Spirochaeta thermophila: position and implications for the systematics of the order Spirochaetales. Syst. Appl. Microbiol. 16:224-226.

28. Rainey, F. A., S. Klatte, R. M. Kroppenstedt, and E. Stackebrandt. 1995. 
Dietzia, a new genus including Dietzia maris comb. nov., formerly Rhodococcus maris. Int. J. Syst. Bacteriol. 45:32-36.

29. Rast, H. G., G. Engelhardt, and P. R. Wallnöfer. 1980. Degradation of aromatic compounds in the actinomycete-genus Rhodococcus. FEMS Microbiol. Lett. 7:1-6.

30. Schleifer, K. H., and O. Kandler. 1972. Peptidoglycan types of bacterial cell walls and their taxonomic implications. Bacteriol. Rev. 36:402-477.

31. Springer, B., P. Kirschner, G. Meyer-Rost, K.-H. Schröder, R. M. Kroppenstedt, and E. C. Böttger. 1993. Mycobacterium interjectum, a new species isolated from a patient with chronic lymphadenitis. J. Clin. Microbiol. 31: 3083-3089.

32. Stackebrandt, E., W. Ludwik, E. Seewaldt, and K. H. Schleifer. 1983. Phylogeny of sporeforming members of the order Actinomycetales. Int. J. Syst. Bacteriol. 33:173-180.

33. Stackebrandt, E., J. Smida, and M. D. Collins. 1988. Evidence of phylogenetic heterogeneity within the genus Rhodococcus: revival of the genus Gordona (Tsukamura). J. Gen. Appl. Microbiol. 34:341-348.

34. Stackebrandt, E., and C. R. Woese. 1981. Towards a phylogeny of the actinomycetes and related organisms. Curr. Microbiol. 5:197-202.

35. Tsukamura, M. 1971. Proposal of a new genus, Gordona, for slightly acidfast organisms occurring in sputa of patients with pulmonary disease and in soil. J. Gen. Microbiol. 68:15-26.

36. Tsukamura, M. 1978. Numerical classification of Rhodococcus (formerly Gordona) organisms recently isolated from sputa of patients: description of Rhodococcus sputi Tsukamura sp. nov. Int. J. Syst. Bacteriol. 28:169-181.

37. Tsukamura, M. 1982. Numerical analysis of the taxonomy of nocardiae and rhodococci. Division of Nocardia asteroides sensu stricto into two species and description of Nocardia paratuberculosis sp. nov. Tsukamura (formerly the Kyoto-I group of Tsukamura), Nocardia nova sp. nov. Tsukamura, Rhodococcus aichiensis sp. nov. Tsukamura, Rhodococcus chubuensis sp. nov. Tsukamura, and Rhodococcus obuensis sp. nov. Tsukamura. Microbiol. Immunol. 26:1101-1119.

38. Tsukamura, M., and I. Yano. 1985. Rhodococcus sputi sp. nov., nom. rev., and Rhodococcus aurantiacus sp. nov., nom. rev. Int. J. Syst. Bacteriol. 35:364-368.

39. Uchida, K., and K. Aida. 1979. Taxonomic significance of cell wall acyl type in the Corynebacterium-Mycobacterium-Nocardia group by a glycolate test. J. Gen. Appl. Microbiol. 25:169-183.

40. Valo, R., and M. S. Salkinoja-Salonen. 1986. Bioreclamation of chlorophenol-contaminated soil by composting. Appl. Microbiol. Biotechnol. 25:68-75.

41. Valo, R. J., M. M. Häggblom, and M. S. Salkinoja-Salonen. 1990. Bioremediation of chlorophenol containing simulated ground water by immobilized bacteria. Water Res. 24:253-258.

42. Van Ginkel, C. G., H. G. J. Welten, J. A. M. de Bont, and H. A. M. Boerrigter. 1986. Removal of ethene to very low concentrations by immobilized $M y c o$ bacterium E3. J. Chem. Technol. Biotechnol. 36:593-598.

43. Yano, I., I. Tomiyasu, K. Kaneda, and S. Imaizumi. 1986. GC/MS analysis of mycolic acid molecular species and contribution to the chemotaxonomy of new Rhodococcus species, p. 567-570. In G. Szabó, S. Biró, and M. Goodfellow (ed.), Biological, biochemical and biomedical aspects of actinomycetes, part B. Académiai Kiadó, Budapest. 